А. К. Білий, О. Ю. Воскобойнік, С. І. Коваленко

Запорізький державний медичний університет

\title{
ОНЛАЙН-ПІДГОТОВКА СТУДЕНТІВ ДО ЛІЦЕНЗІЙНОГО ІСПИТУ “КРОК 1. ФАРМАЦІЯ” З ОРГАНІЧНОЇ ХІМІЇ: ПОТОЧНИЙ СТАН, ПЕРСПЕКТИВИ ВПРОВАДЖЕННЯ
}

\author{
A. K. Biliy, O. Yu. Voskoboynik, S. I. Kovalenko \\ Zaporizhzhia State Medical University
ONLINE TRAINING OF STUDENTS FOR THE KROK 1. PHARMACY LICENSED EXAM ON ORGANIC CHEMISTRY: CURRENT STATUS, \\ PROSPECTS FOR IMPLEMENTATION
}

\begin{abstract}
Мета роботи - розробка нових напрямків удосконалення підготовки студентів до ліцензійного іспиту “КРОК 1. Фармація”. Основна частина. У статті проаналізовано сучасний стан та проблеми підготовки студентів до іспиту. Детально обговорено можливі стратегії, що можуть бути використані університетами для покращення рівня підготовки студентів до іспиту. Запропоновано інноваційний підхід підготовки студентів до іспиту з використанням онлайн-системи, що дозволяє проводити дистанційне тестування у навчальному та контрольному режимах, онлайн-консультації для студентів, аналіз результатів тестування тощо. Для оптимізації роботи системи було проведено детальний аналіз стану її завантаженості залежно від часу доби та дня тижня, а також залежність результативності тестування від названих вище факторів. Одержані результати дозволяють стверджувати про високу затребуваність студентами онлайн-форм навчання загалом, та систем підготовки до ліцензійних іспитів зокрема.

Висновок. Проведений аналіз даних дозволив виявити періоди найбільшої завантаженості онлайн-систем, що дозволить більш ефективно планувати стратегію онлайн-підтримки студентів викладачами.
\end{abstract}

Ключові слова: “КРОК 1. Фармація”; онлайн-підготовка; органічна хімія; аналіз даних.

The aim of the work - development of new approaches for improving the training of students for the licensed exam of KROK 1. Pharmacy.

The main body. The current state and problems of student's preparation for the exam were analyzed. The possible strategies that may be used by universities to improve the student's preparation for the exam were discussed. An innovative approach to training students for the exam using an online system, that allows distance testing in the training and control modes, online counseling for students, analysis of test results, etc. was proposed. Aimed to optimize the work of the system, a detailed analysis of the state of its loading, depending on the time of day and day of the week, as well as the dependence of the testing effectiveness on the abovementioned factors were carried out. The obtained results allow to assert about the high demand of students for online forms of education in general, and the systems of training for licensing exams in particular.

Conclusion. The data analysis made it possible to identify the periods of the highest occupancy of online system, that would allow more effectively to plan the strategy of the online support of the students by tutors.

Key words: KROK 1. Pharmacy; online training; organic chemistry; data analysis.

Вступ. Медицина та фармацевтика завжди відносились до сфер діяльності, де вимоги до рівня підготовки фахівців є вкрай високими, адже ціною професійної непридатності може стати здоров’я та навіть життя людини. Таким чином, контроль якості освіти осіб, що здобувають освіту лікаря або провізора, стає дійсно питанням життя або смерті. Враховуючи зазначене, у вищих навчальних закладах, що ведуть підготовку майбутніх лікарів

(ㄱ А. К. Білий, О. Ю. Воскобойнік, С. І. Коваленко та провізорів, більшості країн створена потужна внутрішня система оцінки знань студентів на всіх етапах навчання, метою якої $\epsilon$ недопущення одержання диплома особою з сумнівною кваліфікацією. Тим не менш, багато країн пішли шляхом створення єдиних національних екзаменів, які б мали гарантувати високий рівень підготовки медичних та фармацевтичних фахівців. У США це USMLE (United States Medical Licensing Examination) триступенева система екзаменів, яка необхідна 
для одержання диплома лікаря та ліцензії на медичну практику. Аналогічні форми контролю $є$ у Франції, Германії, Великобританії [1]. Ліцензійні екзамени існують і в системі фармацевтичної освіти: Pharmacist Evaluating Examination в Канаді, North American Pharmacist Licensure Examination (NAPLEX) в США, а з 2009 року ліцензійні іспити стали невід’ємною складовою контролю якості фармацевтичної освіти в Україні.

Необхідно зазначити, що з моменту впровадження ліцензованих іспитів вони стають серйозним викликом як для студентів, так і викладачів та залишаються ним до сьогодні.

Огляд даних, що представлені в аналітичних довідках Центру тестування при МО3 України [2, 3], вказує на вкрай загрозливу ситуацію зі складанням ряду ліцензійних іспитів, зокрема “Крок 1. Фармація”. Так, у 2016 році в середньому по Україні 19,23 \% вітчизняних студентів та 24,4 \% іноземних студентів (російська мова навчання) не змогли набрати необхідні для складання 60,5 \% правильних відповідей. В 2017 році вже 32,4 \% вітчизняних та 86,2 \% іноземних студентів (російська мова навчання) не змогли скласти іспит. Також значно погіршились результати за окремими дисциплінами, зокрема з органічної хімії. Так, у 2016 році національний показник результатів складання ліцензійного іспиту “Крок 1. Фармація” студентами-громадянами України за субтестами з органічної хімії склав 70,2 \%, а в 2017 році - 54,7 \%.

Такі необнадійливі результати не могли не привернути увагу адміністрацій ВНЗ та професорськовикладацького складу, які зацікавлені у збереженні контингенту студентів, підвищенні рівня їх кваліфікаційних знань, та спонукали до розроблення стратегії покращення результатів ліцензійного іспиту “Крок 1. Фармація”. Зазвичай такі стратегії зводяться до модифікації навчального процесу 3 дисциплін, що входять до ліцензійних іспитів (введення обов'язкового тестування на кожному практичному занятті, детальний аналіз тестів за темою практичних занять), та введення додаткових занять, як правило, лекцій, повністю присвячених підготовці до ліцензійного іспиту [4, 5]. На нашу думку, обидва шляхи мають суттєві недоліки. В більшості випадків приділення значної уваги тестовим завданням під час практичних занять негативно позначається на навчальному процесі, адже часу може не вистачити на проведення експериментальної роботи та детальне обговорення теми заняття. Що стосується проведення спеціа- лізованих лекцій, то даний підхід згідно з рядом робіт є ефективним [5], однак не слід забувати, що будь-який обсяг педагогічного навантаження, який пов’язаний з підготовкою до ліцензійних іспитів, у навчальному плані є відсутнім.

У таких умовах особливо цінною є самостійна робота студентів, які також безумовно зацікавлені в успішному складанні ліцензійного іспиту, однак така робота потребує підтримки з боку викладачів. Такою підтримкою може стати розробка онлайнкурсів, програмних засобів та контенту, що дозволять студентам дистанційно проходити тестування, одержувати коментарі до тестів, посилання на літературу та відповіді на питання. Зазначена ідея звичайно не є новою, так, певний досвід дистанційної підготовки до складання ліцензійного іспиту “Крок 1. Фармація” описаний Т. М. Бойчук та ін. [6], а співробітниками Запорізького державного медичного університету запропоновані підходи до актуалізації знань студентів на основі технологій дистанційної освіти [7]. Незважаючи на це, наразі не створено досконалої системи онлайн-підготовки до ліцензійних іспитів.

Мета роботи. Враховуючи зазначене, нами поставлено за мету розробити ефективну систему онлайн-підготовки студентів до складання ліцензійного іспиту “Крок 1. Фармація” в рамках навчальної дисципліни “Органічна хімія”. Зазначена система має дозволяти студенту дистанційно проходити тестування як у навчальному (студент бачить, чи правильною була відповідь, коментарі та посилання доступні), так і контрольному режимах (доступний лише фінальний результат тестування), користуватися розширеними коментарями до тестів з посиланнями на літературні джерела, отримувати консультації викладачів он-лайн. У той самий час дана система має дозволяти викладачу проводити всебічний аналіз результатів тестування, що дасть змогу встановити: кількість спроб навчальних та контрольних тестувань, результати тестувань, “проблемні” тестові завдання та інші дані, що дозволять оптимізувати процес підготовки.

Зазначена система була розроблена колективом кафедри органічної і біоорганічної хімії ЗДМУ та в подальшому, окрім основного призначення, була використана для отримання відомостей, які дозволять оптимізувати процес підготовки. Також необхідно відмітити, що існуюча система в будьякому випадку буде потребувати постійного вдосконалення, напрям якого буде залежати від потреб студентів. Таким чином, для встановлення вірних 
напрямків оптимізації роботи системи онлайнпідготовки до ліцензійних іспитів необхідно проводити комплексний аналіз даних, одержаних при роботі студентів, причому мова йде як про результати складання тестів, так і супутню інформацію, як-то час тестування, кількість спроб, динаміка результативності, користування коментарями тощо.

Основна частина. Представлена робота $є$ першою з серії публікацій, присвячених методам удосконалення онлайн-форм навчання студентів з органічної хімії, що планується. В рамках даної статті нами поставлено за мету проаналізувати залежність кількості тестування та їх результативності від дня тижня та часу доби. Дана інформація дозволить більш детально спланувати підтримку студентів он-лайн викладачами кафедри. Дослідження проводилось у період з лютого по вересень 2017 року (період активної підготовки до ліцензійного іспиту “КРОК 1. Фармація” та повторного його складання) серед студентів 3 курсу. За даний період студенти здійснили 861 тестування за субтестами 3 органічної хімії. 3 них 72 у лютому, 338 у березні, 35 у квітні, 395 у червні, 1 у липні, 19 у серпні та 1 у вересні. Такий розподіл обумовлений особливостями організації процесу підготовки до іспиту, наприкінці березня студенти проходять внутрішньоуніверситетські тестування, а у червні - ліцензійний екзамен. Порівняно невелика кількість тестувань у серпні ймовірно обумовлена підготовкою до перескладання іспиту. Таким чином, можна визначити періоди, коли викладачі кафедр мають приділяти особливу увагу консультативній підтримці студентів.

Аналіз залежності кількості тестувань від дня тижня показав, що найбільша кількість тестувань мала місце у вівторок та середу (рис. 1). Це є досить передбачуваним, адже наприкінці тижня студенти втомлені, а у понеділок адаптуються до початку нового навчального тижня. Залежність результативності тестування від дня тижня прослідковується, але, на нашу думку, не є показовою. Нижчий показник результативності у вівторок та середу, на нашу думку, обумовлений більшою вибіркою студентів.

Аналіз залежності кількості тестувань та їх результативності від часу доби (рис. 2) дав можливість зробити такі висновки: найбільша кількість спроб тестування очікувано спостерігається в проміжку часу між 17:00 год та 00:00 год, причому пік завантаження онлайн-системи припав на період 22:00 та 23:00.

Зазначений факт обумовлює певні проблеми 3 організацією онлайн-підтримки студентів викладачами в реальному часі, адже викладачі в цей час не знаходяться на робочому місці. Вкрай цікавою також виявилась інформація про те, що студенти активно тестуються у час, коли в них за розкладом є заняття, що можливо з огляду на те, що розроблена нами система підтримує мобільні платформи. Зазначений факт не можна вважати позитивним, адже якщо припустити, що студенти користуються

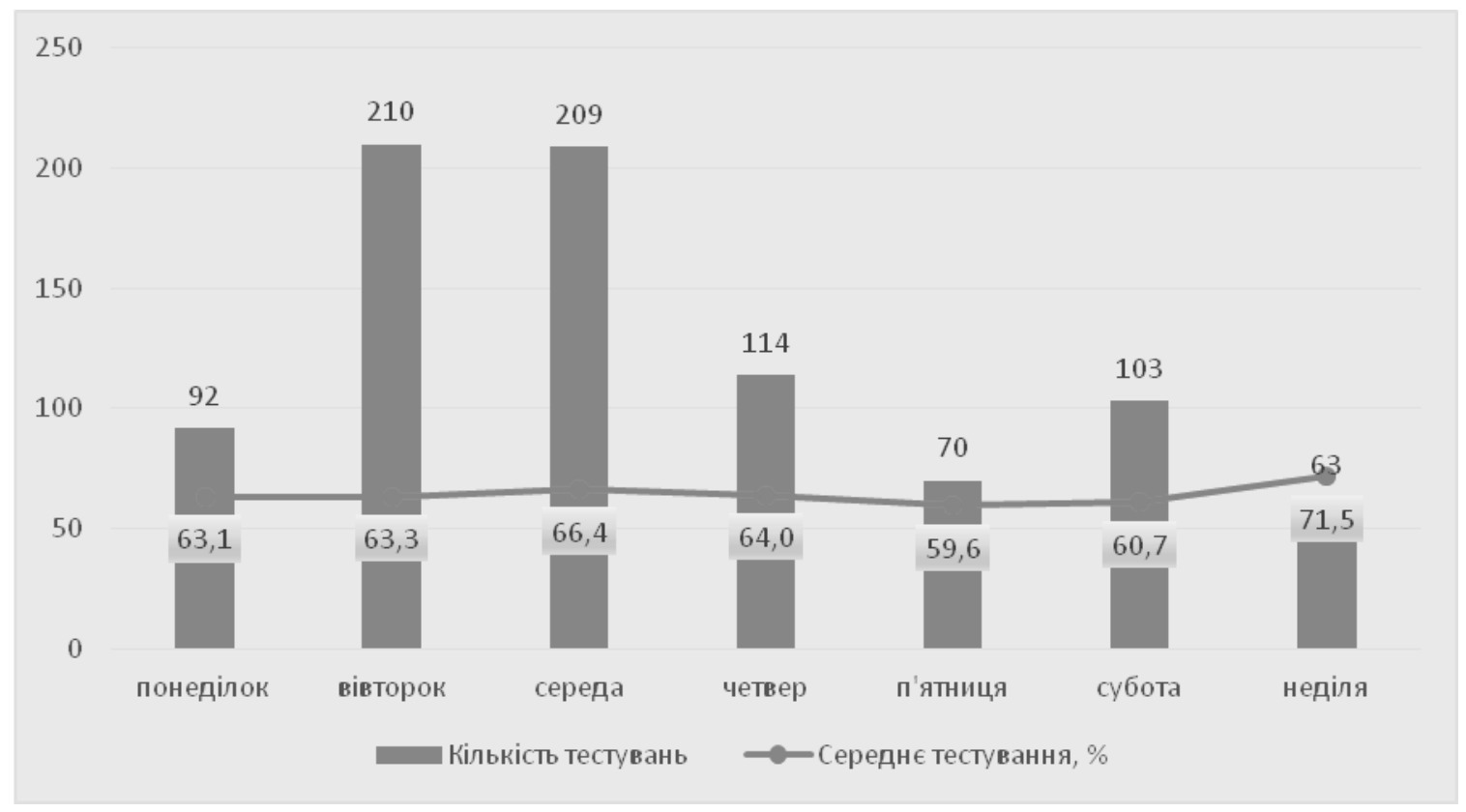

Рис. 1. Залежність кількості тестувань та їх результативності від дня тижня. 


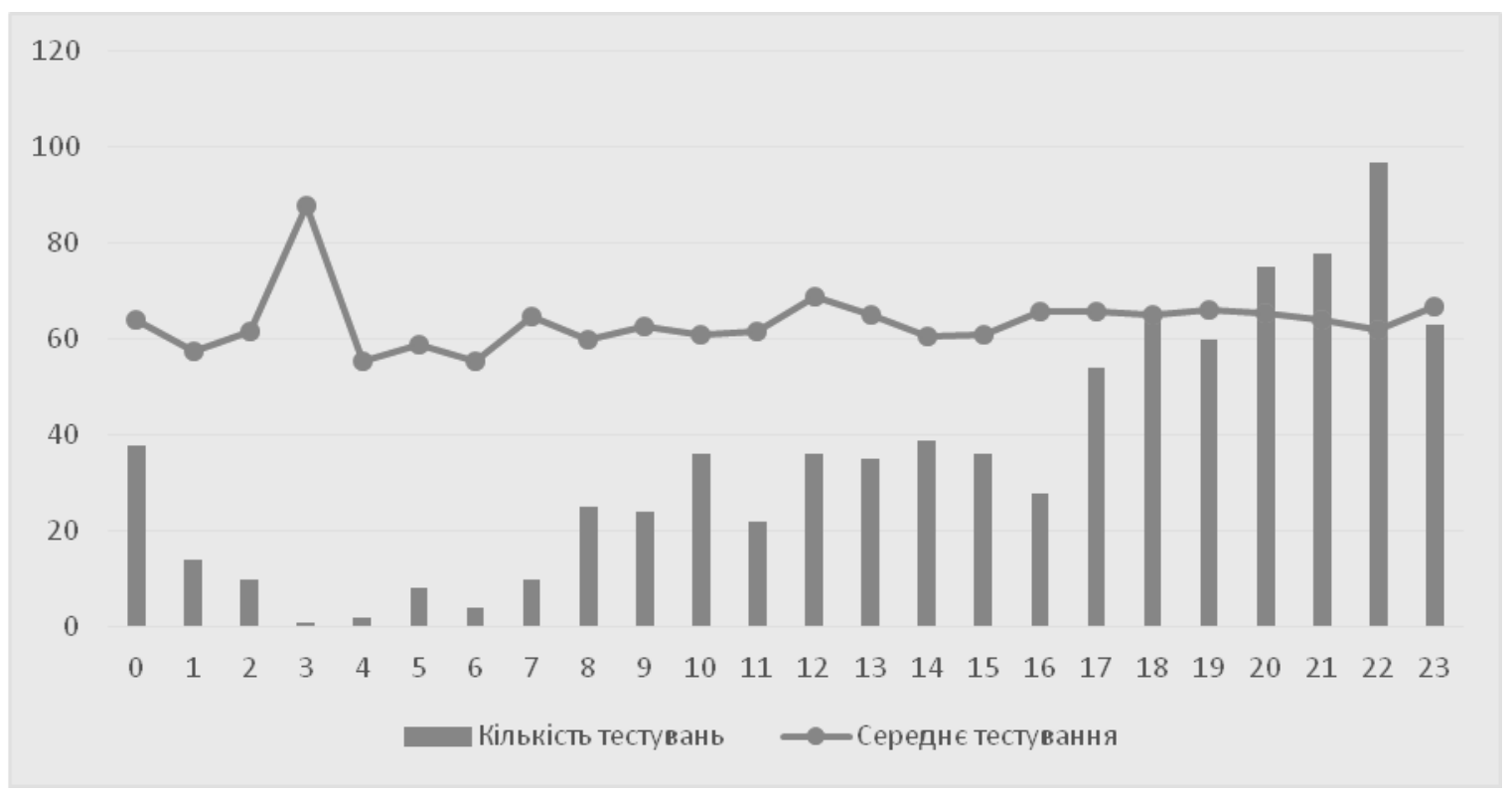

Рис. 2. Розподіл кількості тестувань та їх результативності від часу доби.

онлайн-системою на перервах, то це не дозволяє їм повноцінно відпочити, а якщо під час занять, то це шкодить освітньому процесу. Аналіз результативності тестування показав, що середній відсоток суттєво не залежить від часу доби. Висока результативність у проміжку між 3:00 та 4:00 не $є$ показовою, адже обумовлена нерепрезентативною вибіркою.

Висновки. Одержані результати дозволяють стверджувати про високу затребуваність студентами онлайн-форм навчання загалом, та систем підготовки до ліцензійних іспитів зокрема. Проведений

\section{Список літератури}

1. Xuecheng Li. Status analysis and consideration of medical education system in China and abroad / Li Xuecheng, Liu Shulei // Higher Education of Social Science. - 2012. - Vol. 3, No. 2. - P. 40-44. doi:10.3968/j. hess.1927024020120302.2002.

2. Аналітична довідка Центру тестування МОЗ України до результатів складання ліцензійного іспиту “Крок 1. Фармація” у 2016 році. - https:/www.testcentr.org.ua/ ai/2016/ai-krok1-pharm-04102016.pdf.

3. Аналітична довідка Центру тестування МОЗ України до результатів складання ліцензійного іспиту “Крок 1. Фармація” у 2017 році. - https:/www.testcentr.org.ua/ ai/2017/ai-krok1-pharm-230617.pdf.

4. Філіппова Л. В. Вплив викладання хімічних дисциплін на підготовку до складання ліцензійного іспиту “КРОК-1. Фармація” / Л. В. Філіппова // Інформаційні технології в освіті. - 2010. - Вип. 8. - С. 83-86. doi: 10.14308/ite000207. аналіз даних дозволив виявити періоди найбільшої завантаженості онлайн-систем, що дозволить більш ефективно планувати стратегію онлайн-підтримки студентів викладачами. В той самий час результати дослідження вказують на сумнівну можливість реалізації підтримки студентів у режимі реального часу, адже пік активності студентів не збігається 3 робочим часом викладачів. Більш вірогідною $є$ ефективність організації підтримки, відповідь або пояснення викладача будуть надсилатися студенту на його електронну поштову скриньку або особистий обліковий запис у системі тестування.

5. Панасенко Н. В. Методичні підходи щодо організації настановчих лекцій для ефективної підготовки фармацевтів з органічної хімії до ліцензійного інтегрованого іспиту “КРОК-1. Фармація” / Н. В. Панасенко, О. О. Перепелиця // Буковинський медичний вісник. - 2015. T. 19, № 4 (76).

6. Бойчук Т. М. Досвід впровадження інформаційно-комунікаційних технологій в навчальному процесі Буковинського державного медичного університету / Т. М. Бойчук, I. В. Геруш, В. М. Ходоровський // Медична освіта. - 2012. - № 2. - С. 64-67.

7. Кандибей К. I. Технологія актуалізації знань студента при підготовці до ліцензійного іспиту “КРОК 1. Фармація” на засадах IKT / К. I. Кандибей, О. А. Рижов, В. Г. Корнієвська // Запорізький медичний журнал. 2012. - № 6 (75). - С. 94-96. 


\section{References}

1. Xuecheng, L., \& Shulei, L. (2012). Status analysis and consideration of medical education system in China and abroad. Higher Education of Social Science, 3 (2), 40-44. DOI:10.3968/j.hess.1927024020120302.2002.

2. Analitychna dovidka Tsentru testuvannia MOZ Ukrainy do rezultativ skladannia litsenziinoho ispytu "Krok 1. Farmatsiia” u 2016 rotsi. [Analytical certificate of the Center for testing the Ministry of Health of Ukraine to the results of the licensing exam of KROK 1. Pharmacy in 2016]. Retrieved from: https://www.testcentr.org.ua/ai/2016/aikrok1-pharm-04102016.pdf [in Ukrainian].

3. Analitychna dovidka Tsentru testuvannia MOZ Ukrainy do rezultativ skladannia litsenziinoho ispytu "Krok 1. Farmatsiia” u 2017 rotsi. [Analytical certificate of the Center for testing the Ministry of Health of Ukraine to the results of the licensing exam of KROK 1. Pharmacy in 2017]. Retrieved from: https://www.testcentr.org.ua/ai/2017/aikrok1-pharm-230617.pdf [in Ukrainian].

4. Filippova, L.V. (2010). Vplyv vykladannia khimichnykh dystsyplin na pidhotovku do skladannia litsenziinoho ispytu “KROK-1. Farmatsiia” [Effect of chemical disciplines teaching in preparation for the license examination of KROK 1. Pharmacy]. Informatsiini tekhnolohii v osviti - Information Technologies in Education, 8, 83-86 [in Ukrainian].
5. Panasenko, N.V., \& Perepelytsia, O.O. (2015). Metodychni pidkhody shchodo orhanizatsii nastanovchykh lektsii dlia efektyvnoi pidhotovky farmatsevtiv z orhanichnoi khimii do litsenziinoho intehrovanoho ispytu "KROK -1. Farmatsiia" [Methodological approaches to the organization of prescriptive lectures for effective training of pharmacists in organic chemistry to license integrated examination of KROK 1. Pharmacy]. Bukovynskyi medychnyi visnyk - Bukovynian Medical Journal, 19 (4) (76) [in Ukrainian].

6. Boichuk, T.M., Herush, I.V., \& Khodorovskyi, V.M. (2012). Dosvid vprovadzhennia informatsiino-komunikatsiinykh tekhnolohii v navchalnomu protsesi bukovynskoho derzhavnoho medychnoho universytetu [The experience of introducing information and communication technologies in the educational process of the Bukovyna State Medical University]. Medychna osvita - Medical Education, 2, 64-67 [in Ukrainian].

7. Kandybei, K.I., Ryzhov, O.A., \& Korniievska, V.H. (2012). Tekhnolohiia aktualizatsii znan studenta pry pidhotovtsi do litsenziinoho ispytu "KROK 1. Farmatsiia" na zasadakh IKT [Technology of actualization of student's knowledge in preparation for the licensing exam of KROK 1. Pharmacy on the basis of ICT]. Zaporizskyi medychnyi zhurnal - Zaporizhzhia Medical Journal, 6 (75), 94-96 [in Ukrainian]. 